Молчанова Е. Ю., к.е.н., доцент

Київський національний

торговельно-економічний університет

м. Київ, Украӥна

DOI: https://doi.org/10.30525/978-9934-26-123-7-11

\title{
ДОЦІЛЬНІСТЬ ВПРОВАДЖЕННЯ ІНКЛЮЗИВНОЇ ОСВІТИ В ЗАКЛАДАХ ВИЩОЇ ОСВІТИ
}

Реформування вищої освіти в Україні зумовлена об'єктивними процесами трансформації європейського освітнього простору. Якість вищої освіти повинна відповідати запитам всіх зацікавлених стекголдерів. Орієнтуючись на ринок праці та соціальні умови, доцільно раціоналізувати свої реформи відповідно до державної політики розбудові нової системи освіти, включаючи дуальну та інклюзивну освіту. Практика запровадження дуальної освіти в українських закладах вищої освіти починає стрімко розвиватися. Особливо на рівні технічної освіти та магістерських прикладних програмах. Натомість інклюзивна освіта не закладена в стратегії розвитку вищих навчальних закладів в Україні. Щоб охопити виключені та маргіналізовані групи та забезпечити їх якісною освітою, потрібна розробка та впровадження інклюзивної політики та програм.

Під егідою МОН України були створені інклюзивноресурсні центри - установи, які утворюються 3 метою 
реалізації права дітей з особливими освітніми потребами віком від 2 до 18 років на здобуття дошкільної та загальної середньої освіти, в тому числі, у закладах професійної (професійно-технічної) освіти та інших навчальних закладах, які забезпечують здобуття загальної середньої освіти. До інклюзивно-ресурсних центрів можуть звернутись батьки, які відчувають занепокоєння щодо розвитку дитини віком від 2 до 18 років, незалежно від наявності в дитини інвалідності чи встановленого діагнозу [1]. Отже, ми маємо декілька обмежень - вікове обмеження та лише діти 3 особливими освітніми потребами. Інклюзивна освіта має ширше тлумачення, а іï визначення наводяться в головних міжнародних документах: Стандартних правилах урівняння можливостей інвалідів ООН, Декларації прав дитини ООН, Саламанкській декларації та програмі дій з навчання осіб 3 особливими потребами, Міжнародних консультаціях із питань раннього навчання дітей 3 особливими освітніми потребами [2, с. 47].

За визначенням ЮНЕСКО, інклюзивна освіта - це процес звернення і відповіді на різноманітні освітні потреби дітей через забезпечення їхньої участі у навчанні, культурних заходах і житті громади та зменшення виключення в освіті [3, с. 12]. ЮНЕСКО сприяє інклюзивній освітній системі, яка усуває бар'єри, що обмежують участь та досягнення всіх учнів, поважає різноманітні потреби, здібності та особливості та усуває всі форми дискримінації у навчальному середовищі [4]. Конвенція ЮНЕСКО проти дискримінації в освіті (1960р.) забороняє будь-яке виключення або обмеження можливостей освіти на основі 
соціально обумовлених чи сприйманих відмінностей, таких як стать, етнічне/соціальне походження, мова, релігія, національність, економічний стан, здібності [5].

Отже, наше ставлення до інклюзивної освіти обмежується організацією роботи 3 дітьми з особливими потребами на шкільному рівні. В квітні 2019 р. Міністерство регіонального розвитку, будівництва та житлово-комунального господарства України опублікувала нові Державнобудівельні норми, відповідно до яких «...усі громадські та житлові будівлі, приміщення у них, а також громадський простір мають бути доступними для маломобільних груп населення на рівні з іншими особами. Крім сходів мають обов'язково проектуватися пандуси, ліфти, піднімальні платформи, вертикальні підйомники та інші спеціальні пристрої» [6]. Відповідно до рішення КМУ в українських університетах було зроблені пандуси, ліфти (за наявних технічних можливостей), піднімальні платформи тощо. Однак кожен заклад вищої освіти в України має інклюзивні групи, в яких навчаються 3 різним етнічним/соціальним походження, розмовляють на різних мовах, мають різні національності, економічний стан та здібності. На відміну від західних університетів ми не замислюємося над тим, що вже створили інклюзивні групи. А крім того, не сформовані окремі плани для навчання цих дітей. Найцікавішими кейсами $\epsilon$ нездатність викладачів змусити відвідувати заняття мусульманських студентів під час Рамадану, або викладач не може потрапити до аудиторії, в якій моляться мусульманські студенти. Це лише два приклади, які підтверджують відсутність будь-якої стратегії розвитку 
інклюзивної освіти. Всіх цих студентів ми намагаємося «загнати» в рамки української системи. Натомість слід визначити та сформувати нову стратегію розвитку закладів вищої освіти із врахуванням інклюзії.

Формування такої стратегії повинно грунтуватися на індексі інклюзії [7], адаптований для закладів вищої освіти. В першу чергу це набір матеріалів, які допоможуть університетам пройти процес розвитку інклюзивної освіти. Йдеться про створення спільнот, що підтримують, та сприяння високим досягненням для всього персоналу та студентів. Впровадження даного індексу дозволить вдосконалити освітній процес в самому закладі:

- здійснити самоперевірку, а також визначити перешкоди для навчання, які можуть виникнути;

- вирішувати власні пріоритети змін та оцінювати свій прогрес;

- використовувати його як невід’ємну частину існуючої політики розвитку.

Формування Індексу інклюзії в освіті для зво повинно грунтуватися відповідно до наступних напрямків: оцінювати всіх студентів та співробітників без будь-яких упереджень; соціалізація студентів, особливо студентів 3 особливими потребами; сформувати соціокультурне різноманітне комфортне середовище; знищити всі бар'єри для всіх студентів, які мають бажання навчатися; сформувати політику заохочення до навчання, в першу чергу дітей 3 особливими потребами; визнати права студентів на освіту; створити / покращити умови для викладачів, які працюють в інклюзивних групах; посилити роль університетів у 
формуванні та розвитку цінностей; сприяти взаємовигідним відносинам між університетами та громадами; визнати, що інклюзія в освіті є одним із аспектів інклюзії в суспільстві.

В Британському центрі інклюзивної освіти використовують три групи показників, які можемо використати для створення власного індексу [8]. При адаптації цих показників отримаємо:

А. Створення інклюзивних культур;

А.1. Створення спільноти: кожен відчуває себе бажаним; студенти допомагають один одному; персонал/ викладачі співпрацює один з одним; викладачі та студенти ставляться один до одного 3 повагою; партнерство між персоналом та батьками/опікунами; співпраця з громадами;

А.2. Впровадження інклюзивних цінностей: реалізація очікувань абітурієнтів; усі зацікавлені стейкголдери поділяють філософію інклюзії; однакове ставлення до всіх студентів; персонал/викладачі та студенти виконують свої обов'язки та не порушують права один одного; персонал/ викладачі допомагають подолати бар'єри, які виникають у студентів; ліквідація дискримінаційних практик;

Б. Розробка стратегії інклюзивного розвитку

Б.1. Забезпечення умов вступу для всіх бажаючих: підготовчі курси для іноземців з курсів «культура та релігія в Україні»;

Б.2. Підтримки різноманітності: формування інклюзивних груп; формування індивідуальних завдань для студентів з особливими потребами, або менш обдарованих дітей; формування політики «особливих освітніх потреб»; 
зменшення перешкод для відвідування занять для дітей 3 різних економічним станом; присікання булінгу;

В. Розвиток інклюзивних практик:

В.1. Організація навчання: проведення активних форм навчання за участю всіх студентів;

В.2. Мобілізація ресурсів: залучення усіх доступних інструментів та ресурсів для надання якісної освіти.

Таким чином, ми бачимо, що інклюзивна освіта присутня у всіх закладах вищої освіти України, однак ми маємо трошки обмежене сприйняття щодо поняття «інклюзивна освіта». Друга проблема - вимірювання інклюзії освіти. Нажаль в світі не існує єдиних індикаторів для визначення Індексу інклюзії, адаптовані країнами версії використовують лише на рівні шкіл. Тому ми починаємо працювати над створенням українського центру інклюзивної освіти з власним Індексом інклюзії.

\section{Література:}

1. Інклюзивно-ресурсні центри. URL: https://mon.gov.ua/ua/dlyabatkiv/karta-irc-ta-zakladiv (дата звернення: 07.08.2021).

2. Колупаєва А.А., Таранченко О.М. «Інклюзивна освіта: від основ до практики»: [монографія] / А.А. Колупаєва, О.М. Таранченко. Київ : ТОВ «АТОПОЛ», 2016. 152 с.

3. Порошенко М.А. Інклюзивна освіта: навчальний посібник. Київ : ТОВ «Агентство «Україна», 2019. 300 с.

4. Inclusion in education. URL: https://en.unesco.org/themes/inclusionin-education (дата звернення: 07.08.2021).

5. Convention against Discrimination in Education 1960. URL: http://portal.unesco.org/en/ev.php-URL_ID=12949\&URL_DO=DO_TOPIC \&URL_SECTION=201.html. 
6. В Україні нарешті будуватимуть безпечні пандуси - вступили в дію нові ДБН. URL: https://www.kmu.gov.ua/news/v-ukrayini-nareshtibuduvatimut-bezpechni-pandusi-z-kvitnya-vstupili-v-diyu-novi-dbn.

7. Index for Inclusion developing learning and participation in school. URL: https://www.eenet.org.uk/resources/docs/Index\%20English.pdf (дата звернення: 07.08.2021).

8. Centre for Studies on Inclusive Education. URL: http://www.csie.org.uk/resources/inclusion-index-explained.shtml\#indicators (дата звернення: 07.08.2021). 